\title{
Bruguiera (Rhizophoraceae) in the Indo-West Pacific: a morphometric assessment of hybridization within single-flowered taxa
}

\author{
N.C. Duke ${ }^{1}$, X.-J. Ge ${ }^{2}$
}

\section{Key words}

Bruguiera $\times$ rhynchopetala

hybrid

Indo-West Pacific

mangrove

morphometric

Rhizophoraceae
Abstract The first putative hybrid tree species of the genus Bruguiera (Rhizophoraceae), B. $\times$ rhynchopetala, is reported from mangrove forests of China and Australia. It was described from China previously as a variety of $B$. sexangula. The hybrid is acknowledged as $B$. gymnorhiza $\times B$. sexangula with parent species restricted to different parts of the Indo-West Pacific. The hybrid is recognised at north-eastern and south-eastern parts of the overlap area between parent distributions, but it appears absent in western parts. Further local assessments are needed across the range. Hybrid status is supported by: 1 ) intermediate and shared morphological characters; 2 ) distribution limited to areas of co-occurrence of B. gymnorhiza and B. sexangula; and 3) molecular studies. However, compared with other mangrove genera with naturally occurring hybrids, this occurrence is unusual since this intermediate usually has functional flowers and fruits. Full descriptions are given for the new hybrid taxon and three larger, single-flowered Bruguiera taxa, along with distribution maps and a key.

Published on 7 April 2011

\section{INTRODUCTION}

Bruguiera Lam. (Rhizophoraceae), an important mangrove genus in the Indo-West Pacific region, has been described with six species (Wyatt-Smith 1953, Hou 1958, Tomlinson 1986). The genus is well recognized for its Rhizophoraceous foliage of bright, shiny green leaves, trunks with sturdy basal buttresses, and thick, knobbly knee roots. Species are characterised by the number of flower buds in inflorescences, bud size, ribbing on calyces, numbers of calyx lobes, shape of petal lobes, and presence of spines and bristles on petals. Taxa are primarily divided into three morphologically distinct groupings, namely: a group with smaller leaves and multiple-flowered inflorescences of relatively small flowers, comprising $B$. parviflora (Roxb.) Wight \& Arn. ex Griff. and B. cylindrica (L.) Blume; a group of larger leafed entities, with larger flowers in single-flowered inflorescences, being B. gymnorhiza (L.) Savigny, B. sexangula (Lour.) Poir. and B. exaristata Ding Hou; and, a sixth species, $B$. hainesii C.G.Rogers, that cannot be readily attributed to either group since it has an intermediate combination of character states - notably, larger flowers in multiple-flowered inflorescences (Hou 1957, 1958). The focus of this treatment is with the single-flowered group.

The distributional range of the genus, based chiefly on the single-flowered $B$. gymnorhiza, is commonly recognized as widespread, being distributed throughout the Indo-West Pacific from East Africa to Southeast Asia, Australia and the western Pacific (Map 1). In the Asian-Australasian portion of this range, $B$. gymnorhiza overlaps with the more restricted $B$. sexangula. Where they co-occur, there are notable differences in their respective ecological conditions. Most noticeably, $B$. sexangula

\footnotetext{
University of Queensland, School of Biological Sciences Marine Botany Group, Brisbane, Queensland, Australia; corresponding author e-mail: n.duke@uq.edu.au.

2 Key Laboratory of Plant Resources Conservation and Sustainable Utilization, South China Botanical Garden, Chinese Academy of Sciences, Guangzhou 510650, China; e-mail: xjge@scbg.ac.cn.
}

commonly occurs in upstream reaches of freshwater dominated estuaries, whereas $B$. gymnorhiza has a wider tolerance but is more marine and tolerates higher levels of salinity. These distinctive ecological characteristics helped locate and identify introduced B. sexangula in Hawaii (Allen et al. 2000). The third single-flowered taxon, $B$. exaristata, unlike the others, is distinguished by a distinctly southern hemisphere range, extending from Myanmar, Thailand, Malay Peninsula, Singapore to New Guinea and northern Australia (Hou 1958, Percival \& Womersley 1975, Sheue et al. 2005) - a distribution mirrored in the north by $B$. hainesii (Hou 1958). The phylogenetic relationships among these taxa are unknown.

Although no hybrids have been previously described for Bruguiera (Tomlinson 1986, Abeysinghe et al. 1999, 2000), hybrid intermediates are known among three other mangrove genera, namely: Lumnitzera Willd. (Tomlinson et al. 1978), Rhizophora L. (Duke \& Allen 2006, Duke 2006, 2010) and Sonneratia L.f. (Duke \& Jackes 1987). However, Ko (1978) described a variant of $B$. sexangula, namely $B$. sexangula var. rhynchopetala W.C.Ko, from Hainan Island, China. This entity was observed amongst stands of both $B$. gymnorhiza and $B$. sexangula (Ko 1978). The long bristles at the tips of the petals distinguished it from adjacent trees of $B$. sexangula which had very short bristles, or none at all. Although the entity resembled $B$. sexangula in key morphological attributes, our preliminary observations found it to be morphologically intermediate between $B$. sexangula and B. gymnorhiza. These observations, combined with its observed low frequency in the field, were taken as evidence of its likely hybrid origin. Subsequent genetic characterization studies affirmed its status as a distinct hybrid entity (Ge 2001, Ge et al. 2004, Pan et al. 2005, Islam et al. 2006, Zhou et al. 2008).

In this treatment, we extend these observations, and report further evidence for the hybridity of $B$. sexangula var. rhynchopetala which is formally given hybrid status. These findings are based on morphological attributes and ecological data for the 


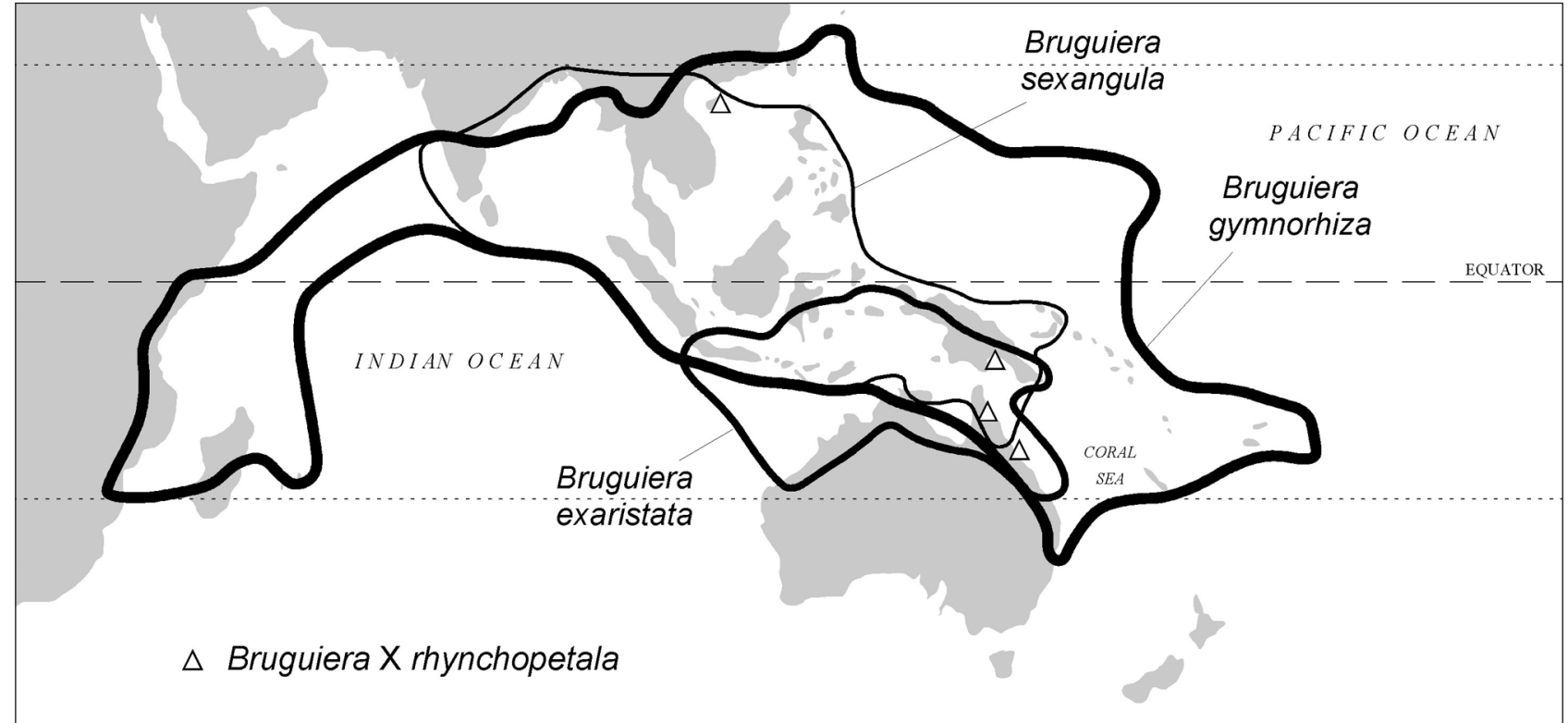

Map 1 Global distributions of the three large, single-flowered Bruguiera species, B. exaristata, B. gymnorhiza and B. sexangula. Note that B. sexangula was introduced to the Hawaiian islands (Allen et al. 2000).

hybrid and three like species taxa. These four larger, singleflowered Bruguiera entities observed in the Indo-West Pacific are described along with distribution maps, ecological notes, a new diagnostic key, and a brief assessment of morphological characters and likely phylogenetic relationships.

\section{METHODS}

\section{Study sites}

From 1998 until 2005, Bruguiera plant material and observations were collected from 17 locations in 8 regional areas throughout the Indo-West Pacific (Table 1). Site access was achieved using a combination of road vehicles, small boat transport, and by foot. Aerial photographs and detailed maps permitted accurate site identification in conjunction with geographical coordinates.

\section{Plant sampling}

Plant material was collected from all four Bruguiera taxa encountered during visits to each location. In summary, all taxa were sampled (with numbers of samples for each entity shown in brackets; see Table 1), including: $B$. exaristata (6), B. gymnorhiza (34), B. $\times$ rhynchopetala (9) and B. sexangula (26). In all, 75 individual tree collections were considered in this treatment. Assessments were made for each sample using a standardised set of morphological measurements and descriptive characters of specific components.

\section{Morphological attributes}

The measurements of morphological character states were taken from intact leafy shoots with mature flower buds, and/or attached mature hypocotyls. All observations and measurements were made from fresh material. Based on these diagnostic reproductive stages, up to 56 numeric and multistate

Table 1 Collections of four Bruguiera species $(B G=B$. gymnorhiza; $B X=B . \times$ rhynchopetala; $B S=B$. sexangula; $B E=B$. exaristata) from seven regions in the Indo West Pacific region, listing: location, collections per species, coordinates and collection dates.

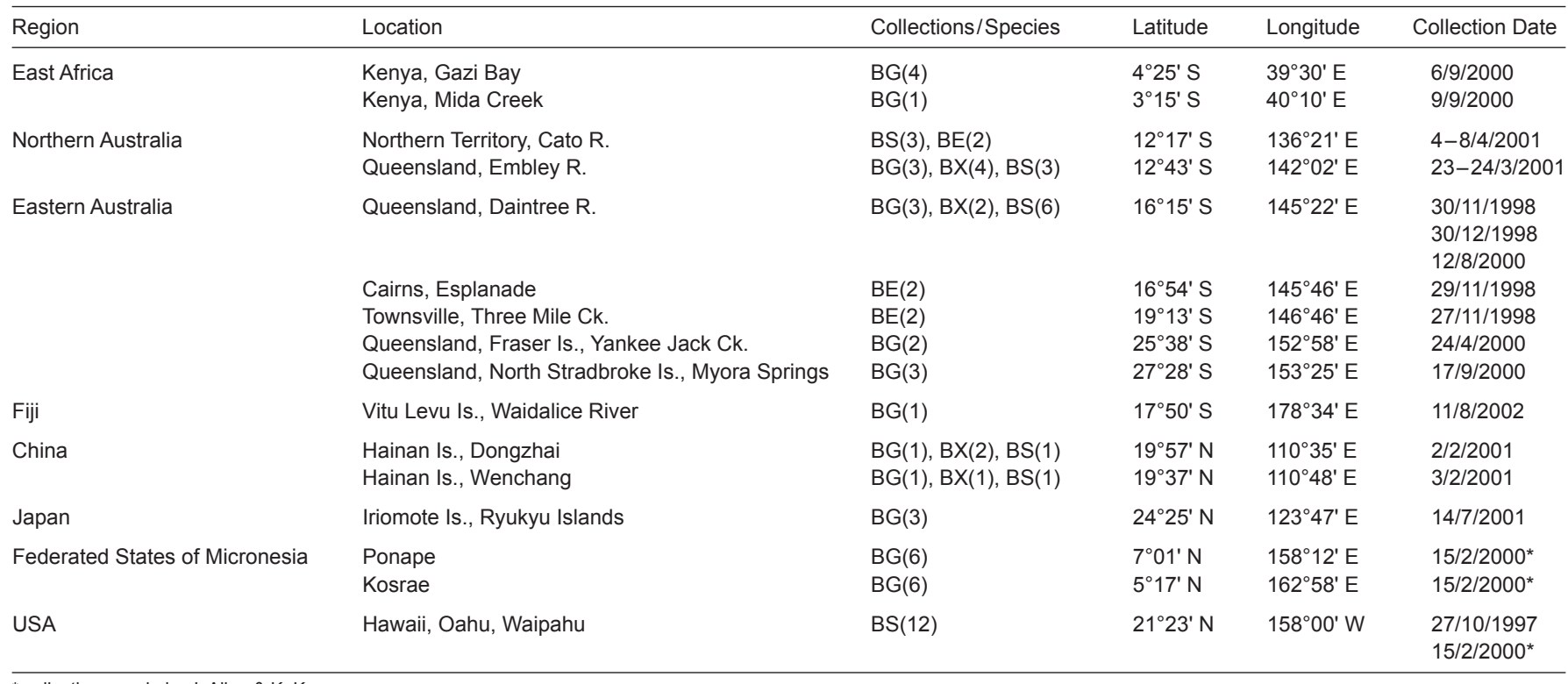




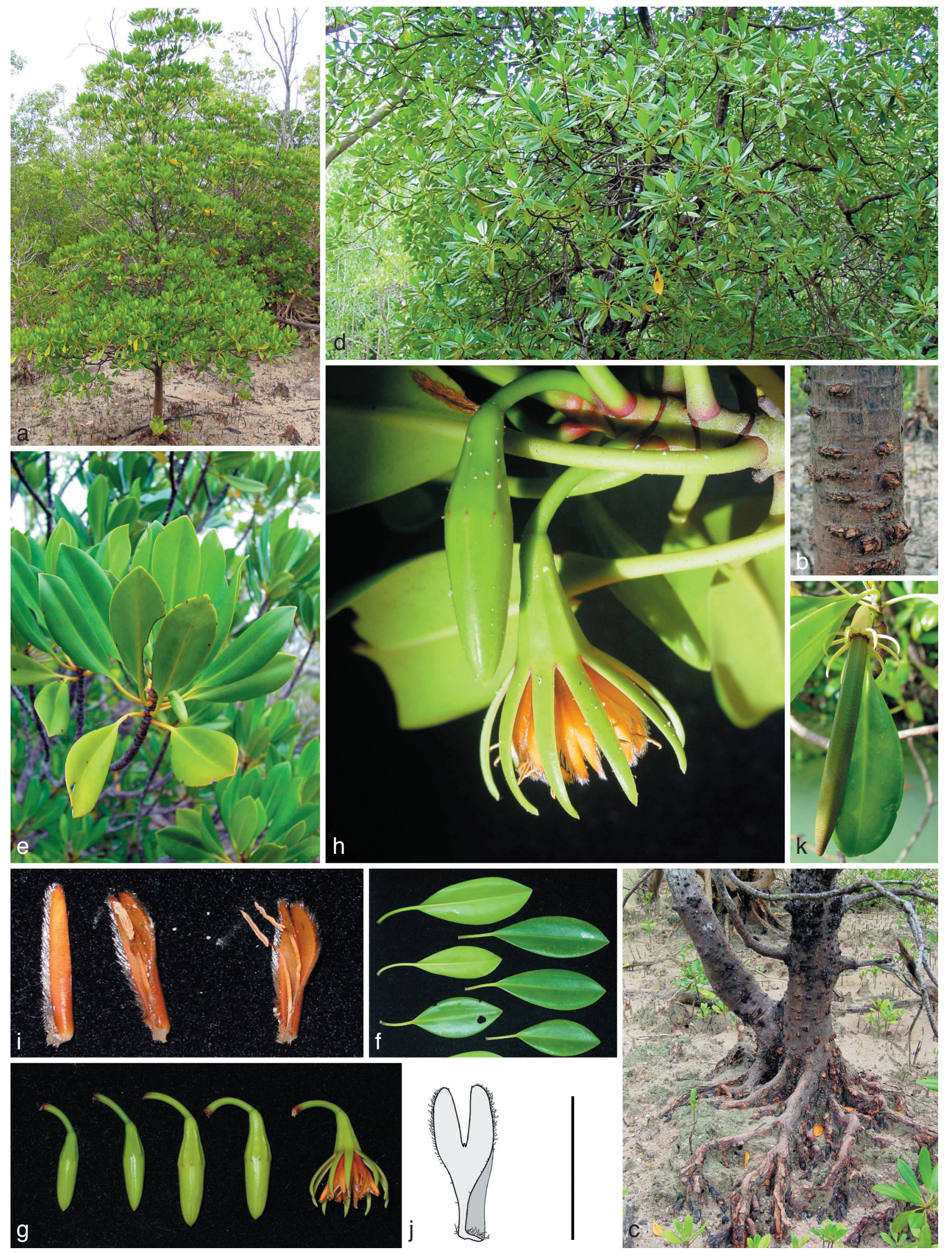

Fig. 1 Bruguiera exaristata Ding Hou. a. Habit, Darwin, Australia; b. bark; c. trunk and exposed roots; d. foliage; e. leafy rosette with mature buds; f. leaves; g. flower buds from immature to mature and open; $h$. open mature flower bud showing petals; i. closed and open petals; j. diagram of open petal; $k$. mature hypocotyl. - Scale bars: $a-j=10 \mathrm{~mm}$. 

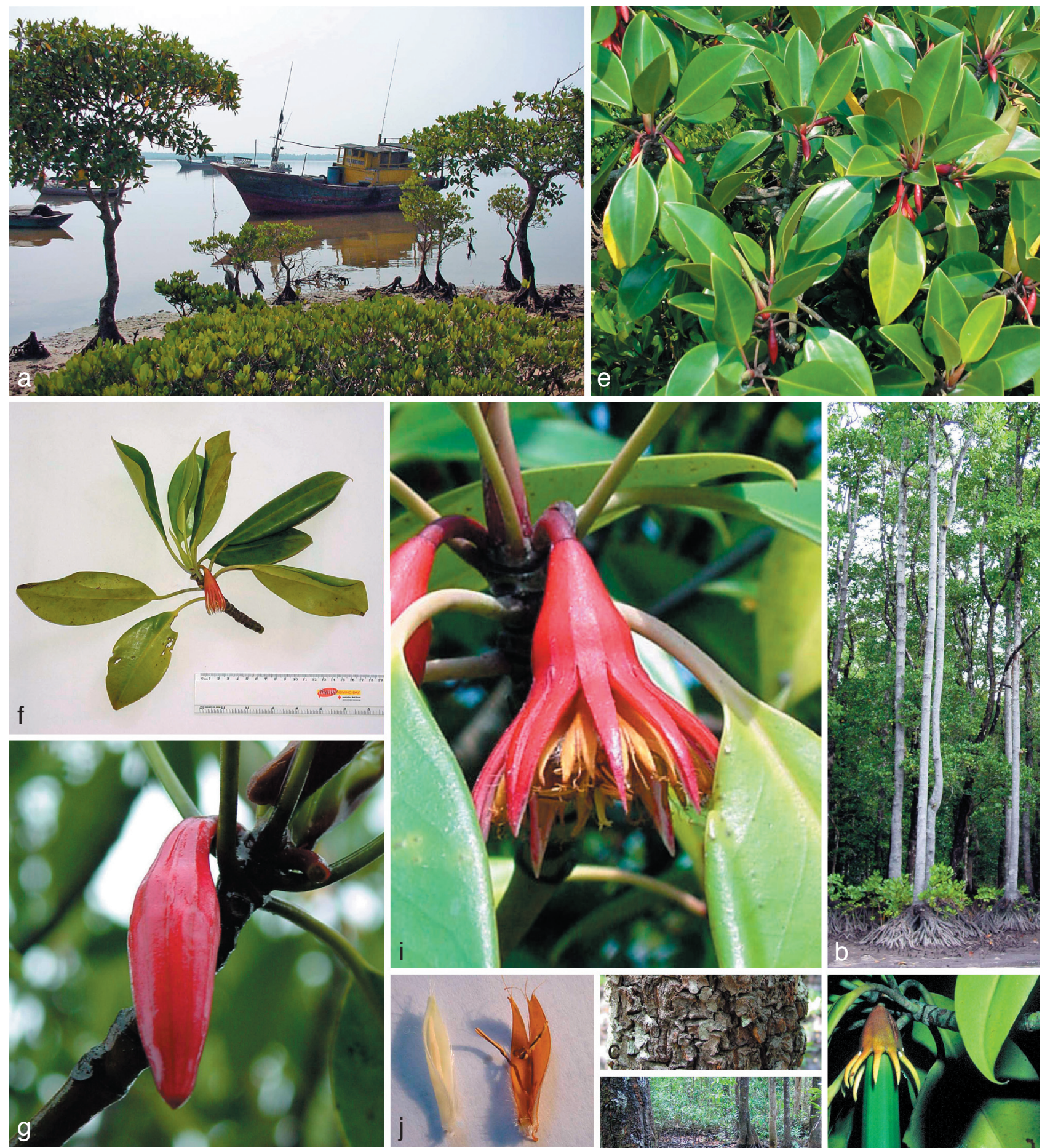

21

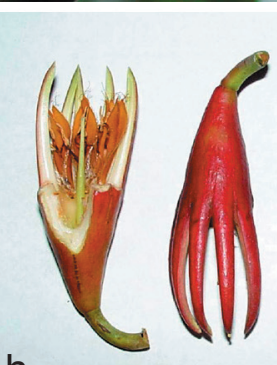

$\mathrm{h}$
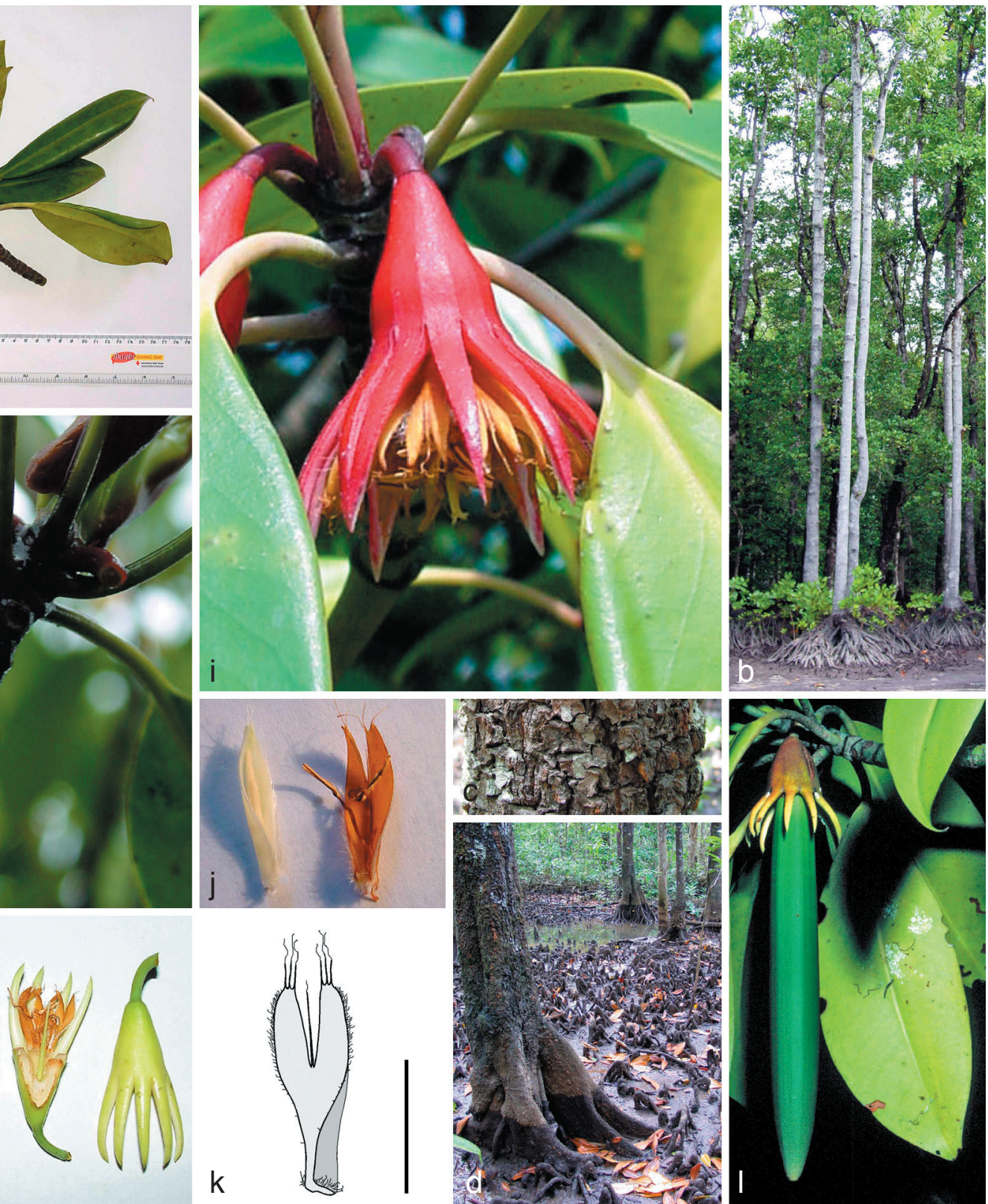

Fig. 2 Bruguiera gymnorhiza (L.) Savigny. a. Habit, Hainan, China; b. tree, Solomon Islands; $c$ bark; d. trunk and exposed roots; e. foliage with inflorescences; f. leafy rosette with open flower bud; g. closed mature flower bud; $h$. mature flower buds of two colour morphs - red and green; i. open flower bud showing petals; j. closed and open petals; k. diagram of open petal; I. mature hypocotyl. - Scale bars: a-k =10 mm. 
Table 2 Listing of 56 numeric and multistate characters of foliage, leaves, inflorescences, mature flower buds and mature hypocotyls used in classificatory analyses (adapted from Allen et al. 2000, Allen \& Duke 2006).

\begin{tabular}{|c|c|}
\hline Grouping (no.) & Characters \\
\hline Foliage (2) & Number of leaves in rosette; apical shoot length. \\
\hline Leaves (6) & $\begin{array}{l}\text { Leaf length }(L) \text {, width }(W) \text {, ratio of length to width }(L / W) \text {, shape length }(S=\text { length from widest width to petiole juncture), } \\
\text { ratio of length to shape length }(L / S) \text {; petiole length. }\end{array}$ \\
\hline Inflorescence (3) & Leaf scar node position at attachment beneath apical shoot of mature flower bud, open flower, mature hypocotyl. \\
\hline Mature flower bud (30) & $\begin{array}{l}\text { Peduncle length, width; calyx tube smooth or ribbed; calyx lobe number, margins indented or smooth or raised; bud distil } \\
\text { tip pointed or blunt; closed bud length, widest width, ratio of length to widest width, calyx tube width, calyx lobe length; } \\
\text { corolla internal diameter; style length from ovary base, length from corolla rim, difference between style lengths (= depth } \\
\text { of nectary), width at corolla, number of tip lobes; stamen length, width; anther length, width; petal length, closed width, } \\
\text { open width, lobe length, lobe tip obtuse or acute; bristle number per lobe, length; spine length, ratio of spine to petal lobe } \\
\text { length. }\end{array}$ \\
\hline Mature calyx (with mature hypocotyl) (8) & Calyx length, widest width, tube width, internal diameter; calyx lobe number, length; peduncle length, width. \\
\hline Mature hypocotyl (7) & $\begin{array}{l}\text { Hypocotyl length }(L) \text {, width at widest point, ratio of length to width, width at plumule end, shape length }(S=\text { length from } \\
\text { widest width to distal end), ratio of length to shape length }(L / S) \text {; plumule length. }\end{array}$ \\
\hline
\end{tabular}

Table 3 Diagnostic morphological attributes, including ranges of key numeric and multi-state characters, of the four Bruguiera taxa with large, single-flowered inflorescences. All measures and observations were taken from fresh material. Codes: $N=$ number; $L=l e n g t h ; W=$ width; $D=$ description.

\begin{tabular}{|c|c|c|c|c|c|}
\hline Component & Attribute & B. gymnorhiza & B. $\times$ rhynchopetala & B. sexangula & B. exaristata \\
\hline Bark & $\begin{array}{l}\text { Fissure } \mathrm{D}^{*} \\
\text { Lenticel } \mathrm{W}^{*}\end{array}$ & $\begin{array}{l}\text { Predominately horizontal } \\
\pm 2 \mathrm{~cm}\end{array}$ & $\begin{array}{l}\text { Horizontal and vertical } \\
1-2 \mathrm{~cm}\end{array}$ & $\begin{array}{l}\text { Vertical } \\
\pm 1 \mathrm{~cm}\end{array}$ & $\begin{array}{l}\text { Horizontal and vertical } \\
\pm 1 \mathrm{~cm}\end{array}$ \\
\hline Leaves & $\begin{array}{l}\text { Leaf L/W } \\
\text { Leaf L/S }\end{array}$ & $\begin{array}{l}1.9-2.8 \\
1.9-2.4\end{array}$ & $\begin{array}{l}2.1-2.6 \\
1.9-2.1\end{array}$ & $\begin{array}{l}2.3-3.5 \\
1.8-2.1\end{array}$ & $\begin{array}{l}1.9-2.2 \\
1.8-1.9\end{array}$ \\
\hline Mature flower buds & $\begin{array}{l}\text { Calyx tube } D^{*} \\
\text { Calyx lobe margin D } \\
\text { Bud tip D } \\
\text { Lobe N } \\
\text { Bud L } \\
\text { Lobe L } \\
\text { Spine/Lobe } \\
\text { Petal bristle N } \\
\text { Petal bristle L* } \\
\text { Petal tip D }\end{array}$ & $\begin{array}{l}\text { Smooth to slightly ribbed } \\
\text { Indented to smooth } \\
\text { Pointed } \\
9.5-15 \\
29-44 \\
17-26 \\
0.5-1.5 \\
2-3 \\
2-3.6 \\
\text { Tending acute }\end{array}$ & $\begin{array}{l}\text { Ribbed, sometimes smooth } \\
\text { Smooth to slightly raised } \\
\text { Pointed } \\
9.3-12 \\
29.4-41 \\
17.2-26 \\
0.5-0.9 \\
2-3 \\
1.2-2.3 \\
\text { Obtuse to acute }\end{array}$ & $\begin{array}{l}\text { Ribbed, rarely smooth } \\
\text { Slightly indented to raised } \\
\text { Pointed } \\
10-12 \\
27.6-34 \\
15.6-20 \\
0.4-0.8 \\
0-3.1 \\
0-1.3 \\
\text { Obtuse }\end{array}$ & $\begin{array}{l}\text { Ribbed } \\
\text { Smooth to slightly raised } \\
\text { Blunt } \\
9-10 \\
22-28 \\
12-14 \\
0-0.1 \\
0-1 \\
0-0.2 \\
\text { Obtuse }\end{array}$ \\
\hline Mature hypocotyls & $\begin{array}{l}\text { Hypocotyl L } \\
\text { Hypocotyl L/S }\end{array}$ & $\begin{array}{l}77-219 \\
1.6-2.8\end{array}$ & $\begin{array}{l}95-144 \\
1.6-2.6\end{array}$ & $\begin{array}{l}24-113 \\
1.5-2.4\end{array}$ & $\begin{array}{l}86-100 \\
2.6-3.2\end{array}$ \\
\hline
\end{tabular}

${ }^{*}$ Characters distinctly noted for Chinese occurrences.

attributes were measured and recorded for each specimen (Table 2). The number of attributes scored largely depended on the available reproductive stages on the date of sampling. This comprehensive selection of measured attributes was defined and standardised during prior detailed assessments of the genus (Allen et al. 2000, Allen \& Duke 2006, Duke 2006). The number of attributes (in brackets) for each specimen unit (see Table 2) include: foliage (2), leaves (6), mature flower buds (30), mature calyx (with mature hypocotyl) (8) and mature hypocotyls (7). These characters were used also in the description of each taxon. Of these morphological attributes, 14 were considered diagnostic (all measurements in $\mathrm{mm}$; * also see Tables 2, 3), including:

- Leaves (2) - leaf shape index (length/width); leaf shape index (length/shape*).

- Mature flower buds (10) - bud tip pointed or blunt; bud length; calyx tube smooth or ribbed; calyx lobe margin indented, raised or smooth; calyx lobe number; calyx lobe length; petal lobe tip acute or obtuse; spine between petal lobes index (spine length/lobe length); bristle at apex of petal lobes - number of bristles, length of bristles.

- Mature hypocotyls (2) - hypocotyl length; hypocotyl shape index (length/shape*).

\section{Classificatory analyses}

A comparative classificatory evaluation was undertaken to investigate patterns in morphological relationships among entities encountered. The analyses used 14 diagnostic attributes of leaves, mature flower buds, and mature hypocotyls. These attribute sets were complete (with no missing data) for 16 regional areas sampled. Replicate specimen data were averaged for putative taxonomic entities. The same dataset was analysed using two standard classificatory techniques, namely Principal Coordinates Analysis (PCA) and Cluster Analysis using Primer-e software (www.primer-e.com). Cluster Analyses were performed using a Bray Curtis Similarity Matrix of Untransformed Group Averages.

\section{RESULTS}

\section{Description of taxa}

Based on the diagnostic characters presented in the key, four single-flowered Bruguiera taxa are recognised a priori in mangroves of the Indo-West Pacific region: B. gymnorhiza, $B$. sexangula, $B$. exaristata and $B$. $\times$ rhynchopetala. These taxa, fully described in this treatment, are notably distinguished by their relatively large, single-flowered inflorescences with bi-lobed petals possessing either no spine between, or a spine shorter than petal lobes, or barely longer.

\section{Numerical analyses}

The numerical analyses show a pattern of morphological similarities that is in accordance with the hybrid status and putative parents of $B \times$ rhynchopetala (Fig. 3). The dendrogram (see Fig. 


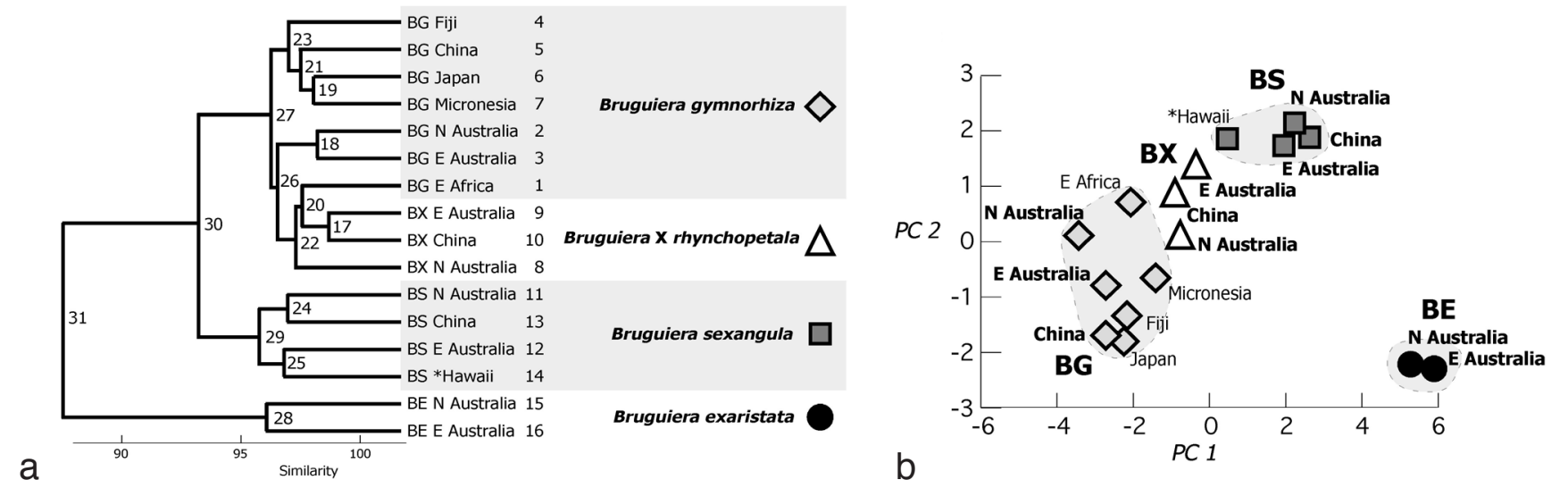

Fig. 3 Plots of numerical analyses using diagnostic attributes of leaves and reproductive components, include: a. cluster analysis dendrogram of the similarity matrix of averaged measures (see Methods); and b. PCA plot with cluster groupings of taxa from 16 locations.

3a) shows species entities grouped according to the a priori classification, but with some conflict in the classification of $B$. gymnorhiza and B. $\times$ rhynchopetala. Fig. $3 b$ shows the first two axes of the PCA-analysis, accounting for $75.2 \%$ of variation in eigenvalues. In this plot, the four entities are distributed roughly in a triangular arrangement - with the three species, $B$. gymnorhiza, B. sexangula and B. exaristata at the corners and the putative hybrid, $B . \times$ rhynchopetala, positioned between the putative parents, B. gymnorhiza and $B$. sexangula. It also shows that while individuals vary across geographic distance, they retain taxonomic affinities and similarities for either of the four taxa - notably along the PC1 axis (Fig. 3b). There are no intermediates between $B$. exaristata and other taxa considered in this study.

\section{Distribution of the putative hybrid intermediate}

While the full distribution of $B$. $\times$ rhynchopetala remains unknown, the range of this intermediate entity, as first approximation, may be defined by the co-occurrence of the parental species $B$. gymnorhiza and $B$. sexangula (Map 2). This potential range extends from southern India and Sri Lanka in the west, to China and the Philippines in the north-east, to New Guinea and north-eastern Australia in the south-east.

\section{KEY TO SPECIES — LARGE, SINGLE-FLOWERED BRUGUIERA}

1. Petal spine absent or minute . . . . . . . 1. B. exaristata

1. Petal spine present, distinct, shorter than lobes* ..... 2

2. Petal bristles at lobe apices, absent or minute . . . . . . . . ... . . . . . . . . . . . . . . . . 4. B. sexangula

2. Petal bristles at lobe apices, $1-3 \ldots \ldots \ldots \ldots \ldots$.

3. Petal bristles 1 or 2 , less than $2 \mathrm{~mm}$ long .......... $\ldots \ldots \ldots \ldots \ldots \ldots \ldots$. . . B. $\times$ rhynchopetala 3. Petal bristles 3 , greater than $2 \mathrm{~mm}$ long 2. B. gymnorhiza

* petal spine longer than lobes, and multiple-flowered inflorescences distinguish small flowered species, B. cylindrica, B. parviflora and B. hainesii.

\section{SPECIES DESCRIPTIONS}

\section{Bruguiera exaristata Ding Hou - Fig. 1; Map 1}

Etymology. 'ex-aristata' means 'without a long bristle-like tip' (in Latin), and refers to the absence of long hairs on petal lobes, and absence of a filamentous spine between petal lobes in this species. Common name is 'rib-fruited orange mangrove' (Australia).

Tree or shrub to $10 \mathrm{~m}$, evergreen, columnar or multi-stemmed, branching mostly sympodial, stem base with spreading, somewhat sinuous, stocky buttresses to $0.3 \mathrm{~m}$ high. Exposed root

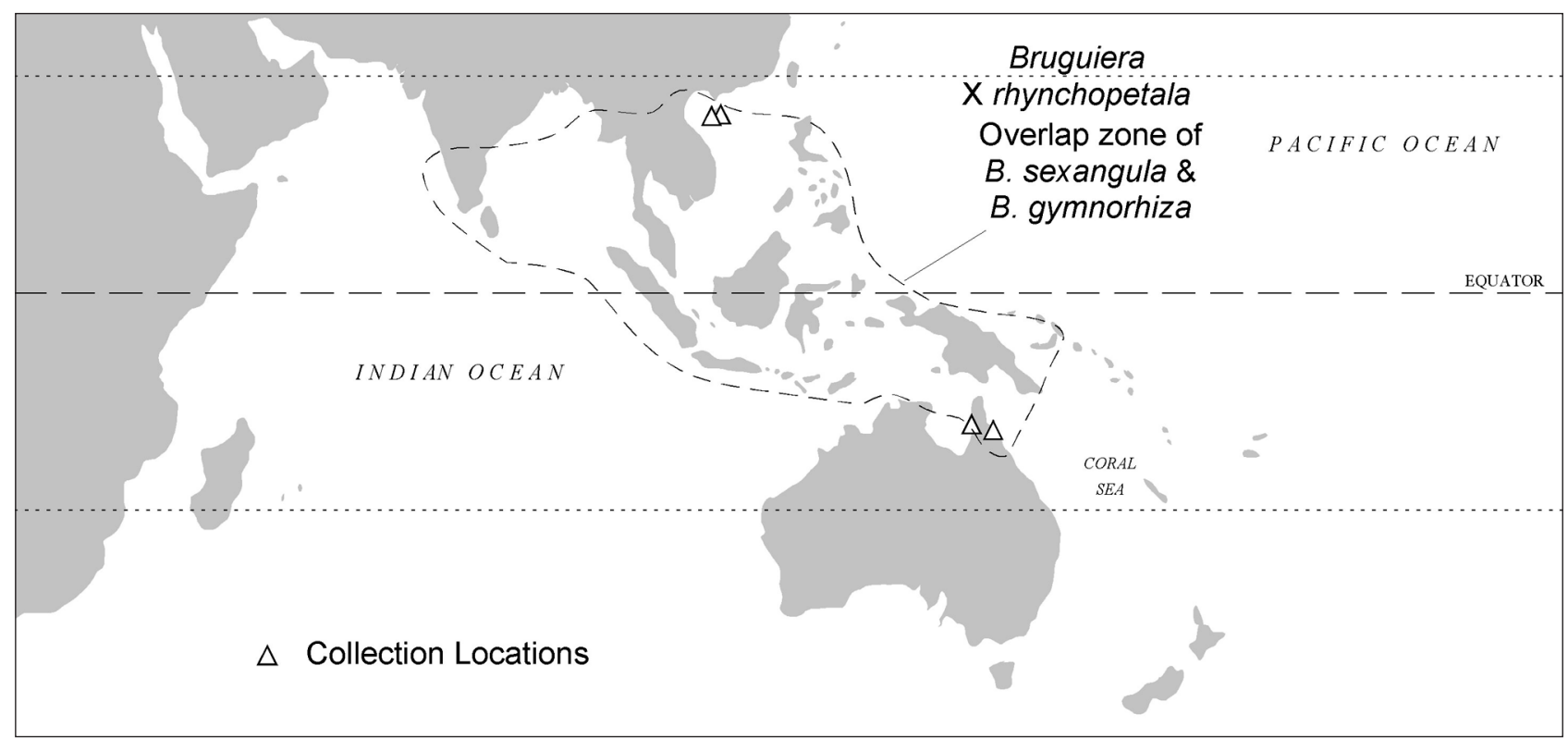

Map 2 Conjectured distribution of Bruguiera $\times$ rhynchopetala, based on the area of overlap for B. sexangula and B. gymnorhiza (see Fig. 1). Collection sites in China and Australia are indicated by triangle symbols. 

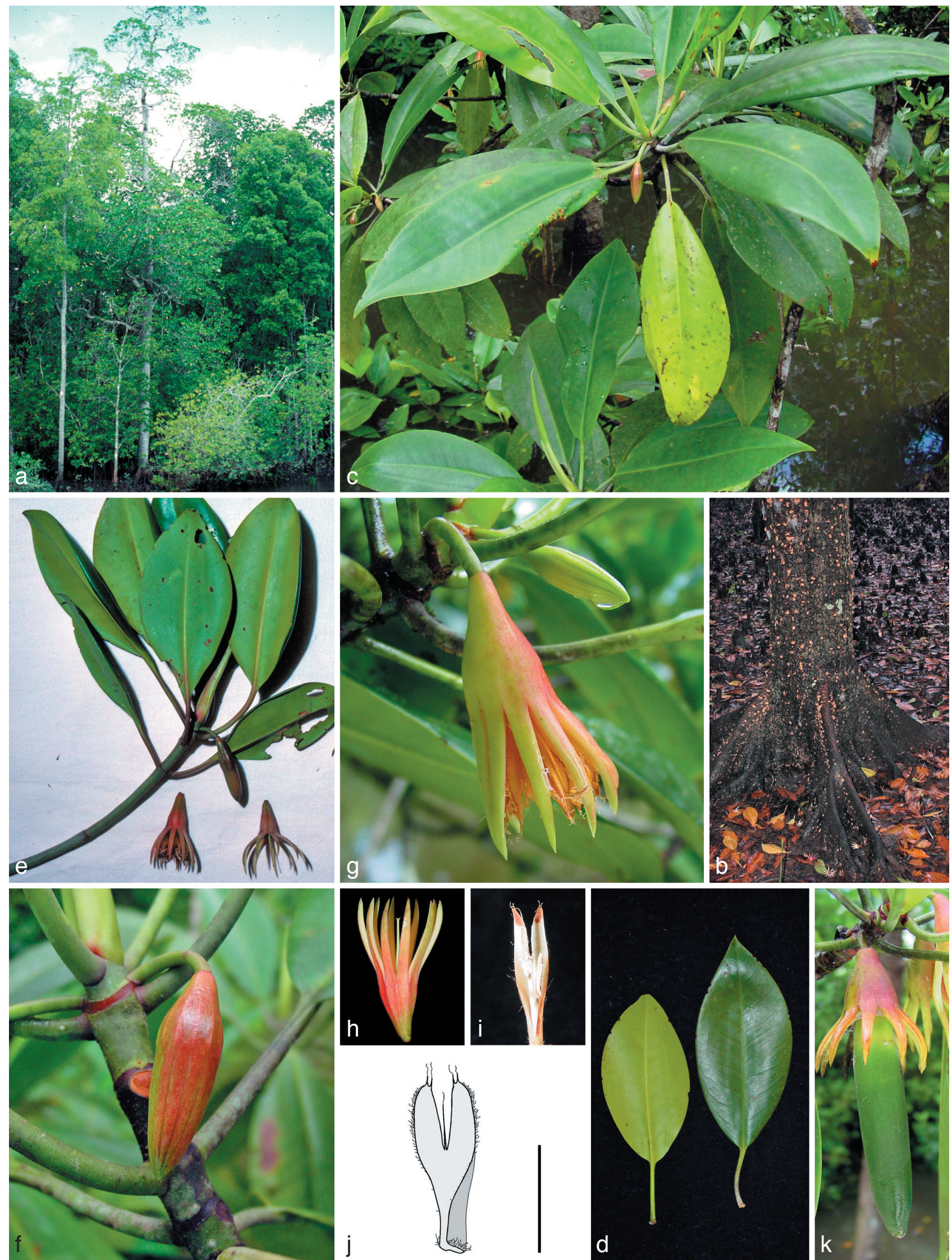

Fig. 4 Bruguiera $\times$ rhynchopetala. a. Habit, Escape River, Queensland, Australia; b. trunk and buttresses, Hainan, China; c. foliage; d. leaves; e. leafy rosette with reproductive parts; f. closed mature flower bud; g. open mature flower bud showing petals; h. immature fruit stage; i. open petal; j. diagram of open petal; k. mature hypocotyl. - Scale bars: $a-j=10 \mathrm{~mm}$. 

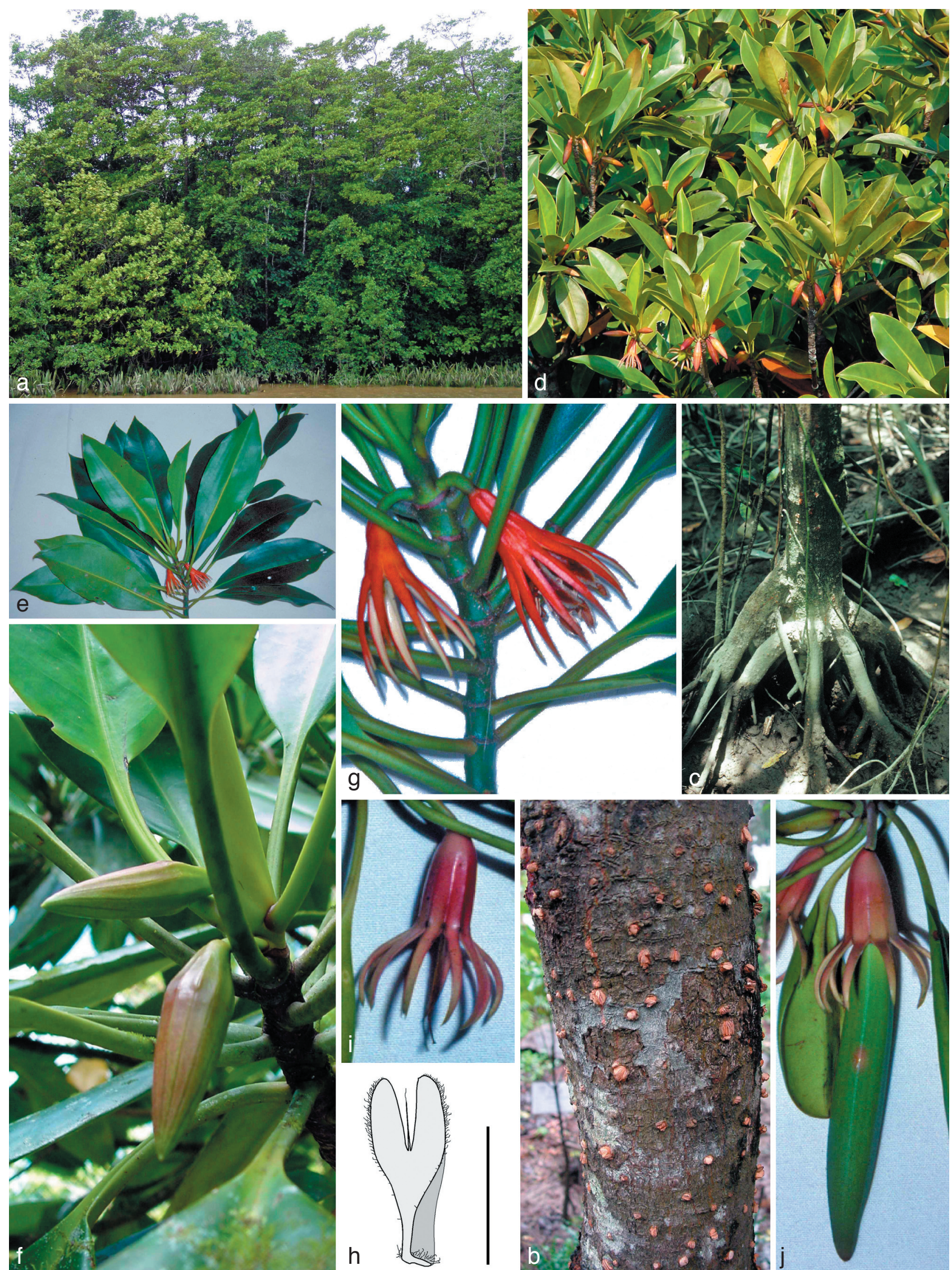

Fig. 5 Bruguiera sexangula (Lour.) Poir. a. Habit, Daintree River, Queensland, Australia; b. bark, Hainan, China; c. trunk and prop-like buttresses; d. foliage; e. leafy rosette with flowers; f. closed mature flower buds; g. open mature flower buds showing petals in one; h. diagram of open petal; i. immature fruit; j. mature hypocotyl. - Scale bars: $\mathrm{a}-\mathrm{h}=10 \mathrm{~mm}$. 
stilts rare, pneumatophores knee-like, thick, to $15 \mathrm{~cm}$. Bark dark grey-brown to black, smooth to rough, friable, horizontal fissures, occasional corky lenticels $\pm 1 \mathrm{~cm}$ diam. Foliage comprised of compact rosettes of paired leaves, clustered at 6-9 leaf scar nodes down from apical shoot, terminal, spicate, prominent, green, 2-4 cm long. Interpetiolar stipules paired, lanceolate, green to yellowish, enclose terminal bud to $4 \mathrm{~cm}$ long. Leaves opposite, simple, obovate, smooth, glossy green, (5-)6$11(-12) \mathrm{cm}$ long, (2-)3-5 cm wide, (3-)4-6(-7) cm shape length (length from widest width to petiole juncture), length/ width ratio $1.9-2.2$, length/shape ratio $1.8-1.9$, often with longitudinal folds, margins entire, acute apex, base cuneate; petiole green, to $1-3 \mathrm{~cm}$ long. Inflorescence axillary, 1-flowered, buds generally nodding, maturing within leafy rosette; peduncle green to (7.9-)8.1-11(-14) mm long, 1.5-2(-2.3) mm wide; mature buds present at 1-2 internodal segments below apical shoot; mature hypocotyls present at 4-5 internodal segments below apical shoot. Mature flower buds yellowish green, 22-28 $\mathrm{mm}$ long, 3.6-4.7 $\mathrm{mm}$ width around calyx tube, 6.3-7.9 mm width at sepal lobes, distil tip rounded; calyx tube turbinate, ribbed, with 9-11 lobes, slender pointed, longer than tube, 12-14 mm long, margins on closed bud raised; petals 9-10, creamy white, turning orange brown at anthesis, $9-13 \mathrm{~mm}$ long, $1.8-2.3 \mathrm{~mm}$ closed width, bilateral folded, $3.3-4.5 \mathrm{~mm}$ open width, bilobed; lobes $2.4-3.8 \mathrm{~mm}$ long, densely fringed with hairs along outer margins, apices rounded, sometimes with a minute bristle to $0.2 \mathrm{~mm}$ long, often absent, sinus between lobes occasionally with minute spine to $0.4 \mathrm{~mm}$ long, often absent; spine/petal lobe length ratio $0-0.1$; stamens $18-20$, creamy white turning orange brown at anthesis, 9.3-12 $\mathrm{mm}$ long, $\pm 0.3 \mathrm{~mm}$ wide, compressed pair within closed petal, dehiscing precociously when triggered, anthers linear, creamy pale yellow turning brown at anthesis, 4.2-5.4 long, $\pm 0.6 \mathrm{~mm}$ wide; style filiform, smooth, pale green, $13-17 \mathrm{~mm}$ long, to $0.7-0.9$ $\mathrm{mm}$ wide, stigma minutely 3 -4-lobed at tip, mounted centrally within calyx bowl 2.5-3.6 mm wide, 2.9-3.8 mm deep. Mature fruit cryptic within slightly enlarged calyx tube, turbinate, ribbed, $\pm 27 \mathrm{~mm}$ long, 6.1-12 mm wide, lobes usually reflexed, 10-12 $\mathrm{mm}$ long, 15-22 mm spread width; germination viviparous, hypocotyl emergent from calyx with maturation. Mature hypocotyl finger-like, slender, straight, green, 8.6-10 cm long, 9-10 $\mathrm{mm}$ at widest point, $31-37 \mathrm{~mm}$ shape length (length from widest point to distil end), $\pm 3 \mathrm{~mm}$ wide at plumule end, length/width ratio 9-10.5, length/shape ratio $2.6-3.2$, slight longitudinal ribbing, distil end blunt, plumule 1-1.8 mm long, buoyant dispersal agent.

Phenology — In the southern hemisphere, notably Australia, flowering peaks during September and October, and propagule maturation occurs during February and March.

Ecology and local influences - Common constituent of the upper intertidal mangrove zone and intermediate-upstream estuarine position. In Australia, the species is found in a variety of habitats ranging from tidal backwaters, to stunted stands bordering saltpans and sandy beaches. Common associates include Ceriops australis and Xylocarpus moluccensis. As with other Bruguiera, this species has a distinctive explosive pollen release mechanism. Honey-eaters frequently visit the flowers to gather nectar.

Distribution - Distributed from eastern Indonesia, Timor and southern New Guinea to northern Australia. In Australia (Duke 2006), the species occurs in estuaries across the north coast from the Montebello Islands and Cossack, Western Australia $\left(20^{\circ} 40^{\prime} \mathrm{S}, 117^{\circ} 12^{\prime} \mathrm{E}\right)$ in the west, across the Northern Territory, to Port Curtis, Queensland $\left(23^{\circ} 49^{\prime} \mathrm{S}, 151^{\circ} 22^{\prime} \mathrm{E}\right)$ in the east.

Note - Bruguiera exaristata is readily recognised by its buttressed trunk, knee-like pneumatophores, opposite glossy green leaves, and moderately-large mostly solitary flowers with 8-10 lobes. The calyces are notable for their light green colour and distinctive ribbing. The species is distinguished from other single flower Bruguiera by the absence of an appreciable spine between petal lobes, and the absence of bristles on petal lobes.

\section{Bruguiera gymnorhiza (L.) Savigny - Fig. 2; Map 1}

Etymology. 'Gymno-rhiza' means 'naked root' (in Greek), and refers to the conspicuous exposed knee roots of this species. Common name is 'largeleafed orange mangrove' in Australia. There has been confusion regards the spelling of 'gymnorhiza'. The epithet was published by Linnaeus with one ' $r$ ' and quoted by Savigny in Lamarck \& Poiret (1798) with one ' $r$ ' as well. However, more recent authors have used double 'r', such as Ding Hou (1958), Tomlinson (1986) and Wagner et al. (1990). Based on such usage, two 'r's are used by the ITIS data being derived from the USDA PLANTS database. The decision to make the change to one ' $r$ ' was based on the International Code for Botanical Nomenclature which states that the original spelling is to be used unless it has an error of a type that ought to be corrected, like the spelling. The question of one ' $r$ ' or two therefore depends on the Greek term from which this epithet was derived. Some recent authors had taken the view that this derivative used a double ' $r$ ', so Linnaeus' spelling was corrected. However, others like the APNI, had taken a conservative view. A high-level working group of plant taxonomists representing all key Australian Herbaria (unpublished minutes, 17 October 2005) have justified retention of Linnaeus' original spelling, following Stearn (1992) p. 261, who specifically discusses the case of '-rhiza' in Greek compounds, and concludes that either spelling is equally acceptable.

Tree or shrub to $25 \mathrm{~m}$, evergreen, columnar or multi-stemmed, branching mostly sympodial, stem base with spreading sinuous, stocky buttresses to $0.5 \mathrm{~m}$ high. Exposed root stilts rarely on lower stem, pneumatophores thick knee-like, to $30 \mathrm{~cm}$. Bark dark grey-brown to black, rough, friable, predominately horizontal fissures, with large corky lenticels of $\pm 2 \mathrm{~cm}$ diam, especially on buttresses. Foliage comprised of compact rosettes of paired leaves, clustered at 4-9 leaf scar nodes around apical shoot, terminal, spicate, prominent, red-green, 3-7 cm long. Interpetiolar stipules paired, lanceolate, often reddish or green to yellowish, enclose terminal bud to $7 \mathrm{~cm}$ long. Leaves opposite, simple, blade elliptic-oblong, coriaceous, glossy green, (8-)9-19(-24) cm long, (3-)4-8(-9) cm wide, (4-)5-9(-12) cm shape length, length/width ratio 1.9-2.8, length/shape ratio $1.9-2.4$, with longitudinal folds, margin entire, apex bluntly pointed, base cuneate; petiole green, to $2-5 \mathrm{~cm}$ long, often glaucous with white waxy coating. Inflorescence axillary, 1-flowered, buds generally nodding, maturing within leafy rosette; peduncle green, (8.7-)10-20(-23) mm long, 2-3.3 mm wide; mature buds present at 1-2 internodal segments below apical shoot; mature hypocotyls present at 4-6 internodal segments below apical shoot. Mature flower buds bright red, occasionally yellowish green, 29-44 mm long, 4.5-18 $\mathrm{mm}$ wide around calyx tube, $8.5-14 \mathrm{~mm}$ at sepal lobes, distil tip acute; calyx tube turbinate, grooved or smooth, with 9-15 lobes, slender, pointed, longer than tube, 17-26 mm long, margins on closed bud indented to smooth; petals 9-15, creamy white, turning orange brown at anthesis, $12-20 \mathrm{~mm}$ long, 1.8-3.1 mm closed width, bilateral folded, 3.5-5.7 mm open width, bilobed; lobes $2.3-8.1 \mathrm{~mm}$ long, densely fringed with hairs along outer margins, apices acute with $2-3$ bristles, 2-4 mm long, sinus between lobes with hair-like spine, 2.5-7.3 $\mathrm{mm}$ long, often exceeding lobes, spine/petal lobe length ratio $0.5-1.5$; stamens $18-30$, creamy white turning orange brown at anthesis, $10-18 \mathrm{~mm}$ long, $\pm 0.5 \mathrm{~mm}$ wide, compressed pair within closed petal, dehiscing precociously when triggered, anthers linear, creamy pale yellow turning brown at anthesis, 4.1-7.9 mm long, $\pm 0.8 \mathrm{~mm}$ wide; style filiform, smooth, pale green, $16-26 \mathrm{~mm}$ long, to $0.9-2 \mathrm{~mm}$ wide, stigma minutely 3-4-lobed at tip, mounted centrally within calyx bowl 2.9-6 $\mathrm{mm}$ wide, $4.2-7.8 \mathrm{~mm}$ deep. Mature fruit cryptic within slightly enlarged calyx tube, turbinate, smooth to grooved, $37-49 \mathrm{~mm}$ 
long, 6.8-23 mm wide, lobes slightly reflexed, if at all, 16-23 $\mathrm{mm}$ long, 18-38 $\mathrm{mm}$ spread width; germination viviparous, hypocotyl emergent from calyx with maturation. Mature hypocotyl cigar-shaped, straight, green, 7-22 cm long, 6-22 mm at widest point, 39-93 $\mathrm{mm}$ shape length, 4-17 mm width at plumule end, length/width ratio 5.9-14.7, length/shape ratio 1.6-2.8, longitudinal ribbing, distil end blunt, plumule 1.7-4.3 $\mathrm{mm}$ long, buoyant dispersal agent.

Phenology — In the southern hemisphere, flowering peaks through April to August, and maturation of propagules occurs in January and February. This is expected to differ by six months in the northern hemisphere.

Ecology and local influences - A distinctive and common member of the mid-high intertidal mangrove community, occurring in downstream-intermediate estuarine positions. The species is found in a wide variety of habitat conditions ranging from deep estuarine muds, to sandy beaches, to coral and rocky coastal shorelines. As with other Bruguiera, this species has a distinctive explosive pollen release mechanism. Honey-eaters frequently visit the flowers to gather nectar.

Distribution - One of the most widely-distributed mangrove species, based on its broad longitudinal range in the Indo West Pacific region. The species is found from East Africa through India and the Malay Peninsula to South China, the Ryukyu Islands, Polynesia to Samoa and northern Australia. In Australia (Duke 2006), it occurs in most estuaries along the northern coast from Darwin Harbour, Northern Territory $\left(12^{\circ} 25^{\prime} \mathrm{S}\right.$, $\left.130^{\circ} 48^{\prime} \mathrm{E}\right)$ in the west, across Queensland, to Moonee Creek, New South Wales $\left(30^{\circ} 13^{\prime} \mathrm{S}, 153^{\circ} 10^{\prime} \mathrm{E}\right)$ in the east.

Note - Bruguiera gymnorhiza is distinguished by its open flowers showing petals with 3 longish bristles at lobe tips. Bruguiera gymnorhiza is notably distinguished from other Bruguiera by a number of characteristics: - large, single-flowered inflorescences with petals having a spine roughly the same length as the paired lobes, as distinct from much longer spines of $B$. cylindrica, B. hainesii and B. parviflora; and, its acute petal lobes with 3-4 bristles, being distinct from the more rounded petal lobes and fewer bristles of $B$. sexangula, $B . \times$ rhynchopetala and $B$. exaristata. The calyces of $B$. gymnorhiza are often also distinctly bright red, almost scarlet in colour, but not always. Some trees have pale yellowish green coloured calyces, and no red ones. Trees with either red or green colour sometimes occur in mixed stands, like those in Great Sandy Strait and Fraser Island in Queensland, Australia. These same colour morphs occur in other locations, like Yap Islands in Micronesia. Another kind of colour variant is found in New Caledonia. In southern estuaries of this large Pacific island, there are many individual trees with much darker appearance than adjacent, normal 'green' trees. Darker trees appear to have red coloration throughout causing leaves and stems that might otherwise be green, to appear dark brown or dark green. Reproductive parts and apical shoots appear bright red. In each case, no corresponding morphological differences could be found to justify separate taxonomic determination.

3. Bruguiera $\times$ rhynchopetala (W.C.Ko) N.C.Duke \& X.J.Ge, comb. \& stat. nov. - Fig. 4; Map 1, 2

Bruguiera sexangula var. rhynchopetala W.C.Ko, Acta Phyotax. Sin. 16 (1978) 110. - Type: Yue-74, 03190 (IBSC), China, Hainan. Qiongshan, Yanfeng, mangrove, 9 Sept. 1974.

Bruguiera $\times$ rhynchopetala N.C.Duke (2006) 122-123, nom. nud.

Natural hybrid of Bruguiera gymnorhiza (L.) Savigny $\times B$. sexangula (Lour.) Poir. Differs from $B$. sexangula but similar to $B$. gymnorhiza in presence of 2-3 bristles, much greater than $1 \mathrm{~mm}$ long, distinctly exceeding apex of petal lobes. Differs from $B$. gymnorhiza but similar to $B$. sexangula in surface of calyx often with distinct ribbing on tube corresponding to lobe junctures on closed mature buds, spine between petal lobes always shorter than lobes.

Intermediate characters between B. gymnorhiza and B. sexangula include: bristle length on apex of petal lobe, c. 1-2 mm long (bristles of $B$. sexangula $0-1 \mathrm{~mm}$; 2-4 mm for $B$. gymnorhiza); lenticels (notable for China) between $1-2 \mathrm{~cm}$ ( $B$. sexangula C. $1 \mathrm{~cm}$; B. gymnorhiza c. $2 \mathrm{~cm}$ ); and bark (notable for China) with both horizontal and vertical fissures ( $B$. sexangula has vertical; B. gymnorhiza has predominately horizontal) (Table 3).

Etymology. 'rhyncho-petala' means 'beaked petals' (in Greek), and refers to the bristles at the tips of petal lobes of this hybrid species.

Tree or shrub to 15-35 m, evergreen, columnar or multi-stemmed, branching mostly sympodial, stem base with flat, fin-like buttresses to $0.5 \mathrm{~m}$ high. Exposed root stilts occasionally on lower stem, pneumatophores knee-like, to $25 \mathrm{~cm}$. Bark grey to pale-brown, with horizontal and vertical fissures, with a few large corky lenticels of $1-2 \mathrm{~cm}$ diam, especially on buttresses. Foliage comprised of compact rosettes of paired leaves, clustered at 4-8(-10) leaf scar nodes down from apical shoot, terminal, spicate, prominent, red-green, $3-7(-8) \mathrm{cm}$ long. Interpetiolar stipules paired, lanceolate, green to yellowish, occasional pinkish tinge, enclose terminal bud to $8 \mathrm{~cm}$ long. Leaves opposite, simple, blade elliptic to elliptic-oblong, smooth, glossy green, $(6-) 7-15(-21) \mathrm{cm}$ long, 3-6(-8) cm wide, (3-)4-8(-9) cm shape length, length/width ratio 2.1-2.6, length/shape ratio 1.9-2.1, margin entire, apex acute, base cuneate; petiole green, to $2.4-4.4 \mathrm{~cm}$ long. Inflorescence axillary, 1-flowered, buds generally nodding, maturing within leafy rosette; peduncle green, 3.9-19(-23) mm long, 1.9-2.7(-3.2) mm wide; mature buds present at 1-2 internodal segments below apical shoot; mature hypocotyls present at 4-6 internodal segments below apical shoot. Mature flower buds green with rosy blush to all green, 29.4-41 mm long, 4.3-6.1 mm wide around calyx tube, $7.6-10 \mathrm{~mm}$ wide at sepal lobes, distil tip acute; calyx tube turbinate, smooth to ribbed, with 9-12(-13) lobes, slender pointed, longer than tube, $17.2-26 \mathrm{~mm}$ long, margins on closed bud smooth, to slightly indented or slightly raised; petals $9-12$, creamy white, turning orange brown at anthesis, 14-18 mm long, 1.9-2.8 $\mathrm{mm}$ closed width, bilateral folded, 3.5-5.6 mm open width, bilobed; lobes 3.2-6.2 mm long, densely fringed with hairs along outer margins, apices rounded with 1-3 bristles near top, 1.2-2.3 mm long, sinus between lobes with hair-like spine, $2.5-5 \mathrm{~mm}$ long, not exceeding lobes, spine/petal lobe length ratio $0.5-0.9$; stamens $18-24$, creamy white turning orange brown at anthesis, 12.2-18 $\mathrm{mm}$ long, 0.2-0.5 mm wide, compressed pair within closed petal, dehiscing precociously when triggered, anthers linear, creamy pale yellow turning brown at anthesis, 5.6-7.3 mm long, $\pm 0.7 \mathrm{~mm}$ wide; style filiform, smooth, pale green, $17-25$ $\mathrm{mm}$ long, to $0.9-1.5 \mathrm{~mm}$ wide, stigma minutely $3(-4)$-lobed at tip, mounted centrally within calyx bowl $2.7-4.4 \mathrm{~mm}$ wide, $3.4-7.3 \mathrm{~mm}$ deep. Mature fruit cryptic within slightly enlarged calyx tube, turbinate, smooth to ribbed, 41-44 mm long, 14-19 $\mathrm{mm}$ wide, lobes slightly reflexed, if at all, 18-24 mm long, 20-35 mm spread width; germination viviparous, hypocotyl emergent from calyx with maturation. Mature hypocotyl cigarshaped, straight, green, 9-15 cm long, $13-19 \mathrm{~mm}$ at widest point, $39-75 \mathrm{~mm}$ shape length, $4-8 \mathrm{~mm}$ width at plumule end, length/width ratio 5.8-8.6, length/shape ratio 1.6-2.6, some longitudinal ribbing, distil end blunt, plumule $2-3.7 \mathrm{~mm}$ long, buoyant dispersal agent.

Phenology - In Australia, flowering peaks in August and September, and maturation of propagules occurs in September to December. In China, flowering was observed in February to June, and generally differing by around six months in the northern 
hemisphere. The Bruguiera hybrid differs from Rhizophora hybrids as it commonly produces mature-sized and well-formed hypocotyls. By contrast, Rhizophora hybrid individuals rarely produce mature hypocotyls (Duke 2010).

Ecology and local influences - Common in the mid intertidal zone of intermediate-upstream estuarine position. Notable occurrences within the estuarine range of $B$. sexangula, and overlapping with $B$. gymnorhiza. The estuarine range therefore is predominately upstream, favouring more freshwater-influenced estuaries. Usually located in mid to higher intertidal portions of mangrove stands.

Distribution - Distribution in China is restricted to northeastern coast of Hainan Island, but records lacking elsewhere in China. In Australia (Duke 2006), the hybrid occurs in east coast estuaries of Queensland from Jacky Creek (10 $54^{\prime} \mathrm{S}$, $142^{\circ} 32^{\prime} \mathrm{E}$ ) in the north, to the Herbert River (18 $32^{\prime} \mathrm{S}, 146^{\circ} 19^{\prime}$ $\mathrm{E})$ in the southeast. The hybrid may occur only where parental forms co-exist.

Specimens examined. Australia, Queensland, Daintree River, Norman C. Duke, D001, D020 (BRIU). - CHINA, Hainan, Qiongshan, Yanfeng, 26 Sept. 1995, Wang Rui-Jiang 035 (IBSC); Qiongshan, Yanfeng, Shanwei, 3 Oct. 1983, Ko Wan-Cheung 497 (IBSC); Wenchang, Bianhai, Sept. 1979, Ko Wan-Cheung 7 (IBSC); Wenchang, Shagang, 4 Aug. 1957, Li DongSheng \& Zhang Jing-Qing 80292 (IBSC); Wenchang, Qinglangang, March, 1956, CAS Hainan Vegetation Investigation Team 1024 (IBSC); Wenchang, Qinglangang, 16 April 1956, 01055 (IBSC).

Note - Bruguiera $\times$ rhynchopetala is the hybrid of B. gymnorhiza and $B$. sexangula. Discrimination of taxa is based on calyx ribbing, bristle number and petal lobe length. The hybrid entity is distinguished by petals having $1-2$ relatively short bristles at lobe tips. By comparison, $B$. sexangula has no bristles, or at least only very short ones less than $1.25 \mathrm{~mm}$ long, not or barely exceeding the apex of the petal lobe. The hybrid is more comparable with B. gymnorhiza which has petal lobes with 2-3, rarely 4 , bristles of $2-4 \mathrm{~mm}$ long, and distinctly exceeding the apex. In field surveys in China, putative hybrids were identified using intermediate characteristics of bark fissuring and lenticels. In Australia, bark characteristics were not as useful, so initial field identification was based on tree shape being more erect, columnar, with plank-like buttresses.

\section{Bruguiera sexangula (Lour.) Poir. - Fig. 5; Map 1}

Etymology. 'sex-angula' means 'six-angled' (in Latin), and refers to the angular sides of the hypocotyl of this species. Common Australian name is 'upriver orange mangrove'.

Tree or shrub to $15 \mathrm{~m}$, evergreen, columnar or multi-stemmed, branching mostly sympodial, stem base with short, sinous buttresses, to $0.3 \mathrm{~m}$ high. Exposed root stilts often low on stem, pneumatophores knee-like, to $15 \mathrm{~cm}$. Bark grey to pale-brown, with vertical fissures, with few corky lenticels to $1 \mathrm{~cm}$ diam. Foliage comprised of compact rosettes of paired leaves, clustered at 2-5 leaf scar nodes down from apical shoot, terminal, spicate, prominent, red-green, 5-11 cm long. Interpetiolar stipules paired, lanceolate, green to yellowish, occasional pinkish tinge, enclose terminal bud to $8 \mathrm{~cm}$ long. Leaves opposite, simple, blade elliptic-oblong, smooth, glossy green, 7-16(-20) cm long, 3-6(-7) cm wide, 4-9(-11) cm shape length, length/ width ratio $2.3-3.5$, length/shape ratio 1.8-2.1, margin entire, apex acute, base cuneate; petiole green, $1.9-3.5 \mathrm{~cm}$ long. Inflorescence axillary, 1-flowered, buds generally nodding, maturing within leafy rosette; peduncle $4.4-11(-12) \mathrm{mm}$ long, $1.5-2.5(-3.4) \mathrm{mm}$ wide; mature buds present at 1-2 internodal segments below apical shoot; mature hypocotyls present at 3-6 internodal segments below apical shoot. Mature flower buds pink-orange to pale yellowish green, 27.6-34 mm long, $3-8.3 \mathrm{~mm}$ wide around calyx tube, $6.8-9.9 \mathrm{~mm}$ wide at sepal lobes, distil tip acute; calyx tube turbinate, ribbed, with 10-12 lobes, slender pointed, longer than tube, 15.6-20 mm long, margins on closed bud raised; petals 10-12, creamy white, turning orange brown at anthesis, 13.2-16 mm long, 1.9-2.6 $\mathrm{mm}$ closed width, bilateral folded, $3.4-4.6 \mathrm{~mm}$ open width, bilobed; lobes 3.6-6.4 mm long, densely fringed with hairs along outer margins, apices rounded with $0-3$ bristles near top, $0-1.3 \mathrm{~mm}$ long, sinus between lobes with hair-like spine, 1.9-4 mm long, not exceeding lobes, spine/petal lobe length ratio $0.4-0.8$; stamens $20-24$, creamy white turning orange brown at anthesis, $10.5-14 \mathrm{~mm}$ long, $0.1-0.5 \mathrm{~mm}$ wide, compressed pair within closed petal, dehiscing precociously when triggered, anthers linear, creamy pale yellow turning brown at anthesis, 4.1-6.2 mm long, 0.4-0.7 mm wide; style filiform, smooth, pale green, $16.8-21 \mathrm{~mm}$ long, to $0.6-1.5 \mathrm{~mm}$ wide, stigma minutely $3(-4)$-lobed at tip, mounted centrally within calyx bowl 2.2-4 mm wide, $2.4-5.1 \mathrm{~mm}$ deep. Mature fruit cryptic within slightly enlarged calyx tube, turbinate, ribbed, 28.6-38 mm long, 4.1-17 mm wide, lobes reflexed; germination viviparous, hypocotyl emergent from calyx with maturation. Mature hypocotyl cigar-shaped, stout, green, 2-11 cm long, 7-17 $\mathrm{mm}$ at widest point, $10-62 \mathrm{~mm}$ shape length, 3-6 $\mathrm{mm}$ width at plumule end, length/width ratio $3.4-7.8$, length/shape ratio 1.5-2.4, slight longitudinal ribbing, distal end blunt, plumule 0.1-3.2 mm long, buoyant dispersal agent.

Phenology - In the southern hemisphere, notably Australia, flowering peaks in August and September, and maturation of propagules occurs in September to December. In the northern hemisphere, this is expected to differ by around six months.

Ecology and local influences - Bruguiera sexangula is usually found in upstream reaches of river-dominated estuaries in high rainfall areas, in mid intertidal, upstream estuarine positions. Other Bruguiera, especially B. gymnorhiza, dominate lower and intermediate sections of such estuaries. As with other Bruguiera, this species has a distinctive explosive pollen release mechanism. Honey-eaters frequently visit the flowers to gather nectar.

Distribution - Bruguiera sexangula is distributed from India to Asia, through the Indonesian Archipelago to New Caledonia and the northern coast of Australia. In Australia (Duke 2006), the species occurs in estuaries along the northern coastline from the Peter John River, Arnhem Bay, Northern Territory (12 $15^{\prime} \mathrm{S}$, $\left.136^{\circ} 22^{\prime} \mathrm{E}\right)$ in the west, to the Herbert River, Queensland (18 $18^{\circ} 1^{\prime} \mathrm{S}$, $\left.146^{\circ} 19^{\prime} \mathrm{E}\right)$ in the east.

Note - Bruguiera sexangula is distinguished by open flowers showing petals with no (or minute) bristles at lobe tips. Bruguiera sexangula is distinguished from other Bruguiera by: large single-flowered inflorescences and petals having a spine slightly shorter than the paired-lobes, as distinct from those of $B$. cylindrica, B. hainesii and B. parviflora; and blunt petal lobes with single minute or absent bristles, and relatively short hypocotyls, as distinct from B. gymnorhiza and B. $\times$ rhynchopetala.

\section{DISCUSSION}

Relationships between morphological entities in this treatment may be indicative of phylogenetic relationships. Firstly, as shown in the PCA plot (Fig. 3b), the three species are arranged in distinct groupings with the hybrid entities grouped between the putative parents. There is relatively little geographic influence on this pattern with widely occurring collection locations falling within respective species groupings. Secondly, the distance between species groupings based on morphological characters appears to reflect genetic similarity (Ge 2001, Ge et al. 2004, Pan et al. 2005, Islam et al. 2006, Zhou et al. 2008). In this way, the closer placement of $B$. gymnorhiza and $B$. sexangula, with 


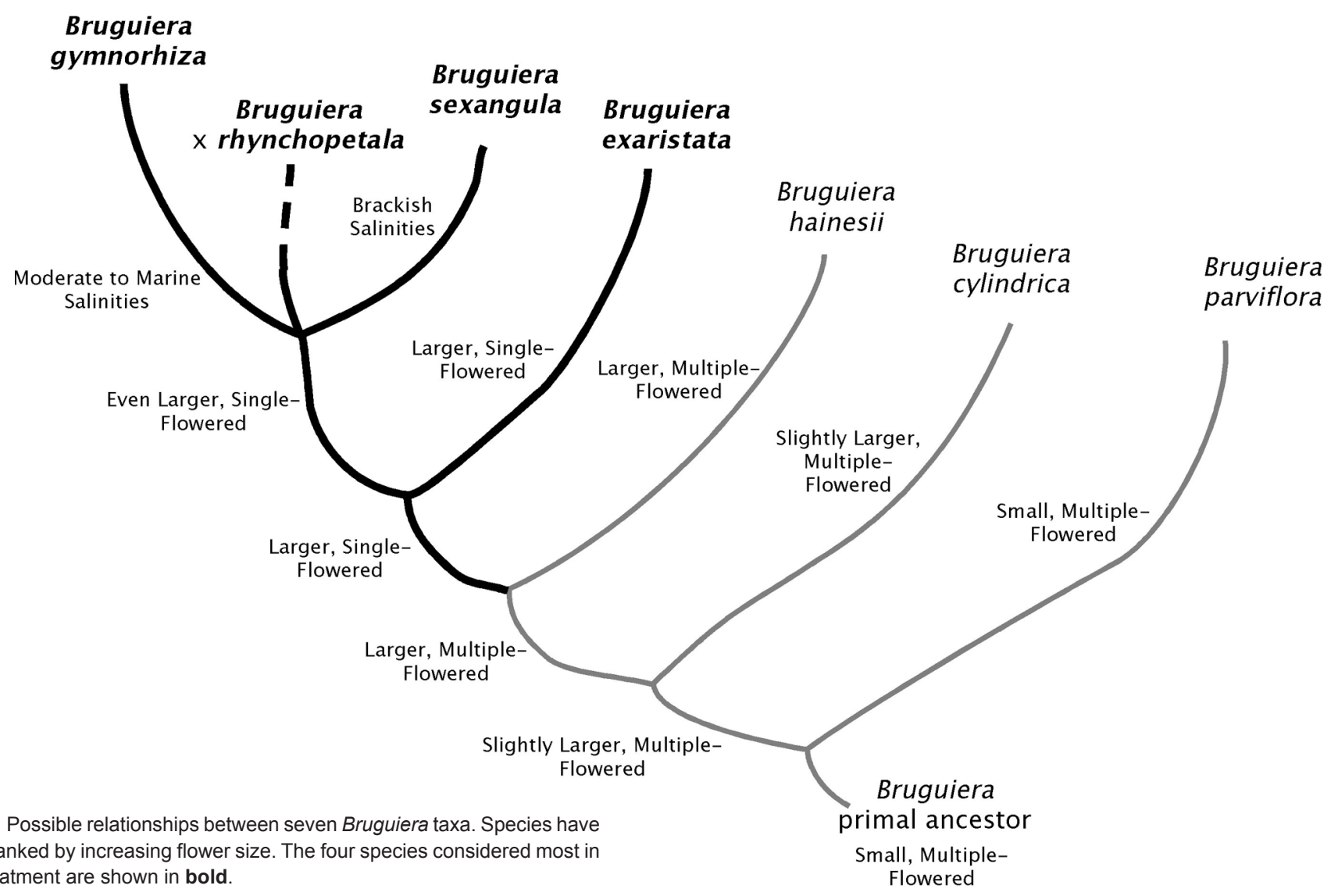

intermediate hybrid, contrasts with the lack of intermediates and the greater distance between B. gymnorhiza and B. exaristata, and between $B$. sexangula and $B$. exaristata.

While this discovery of a hybrid intermediate was made at the eastern portion of the parental overlap zone in both northern and southern hemispheres, this contrasts with comparable investigations in the west. Detailed collections in Sri Lanka found no hybrid intermediate entity (Abeysinghe et al. 1999, 2000). One hypothesis to explain such an occurrence is that populations of $B$. gymnorhiza and $B$. sexangula in the west have greater genetic separation, sufficient to prevent the occurrence of hybrids there - but not in the east. In this way, a shift in genetic distance between parents across the overlap of their respective distributional ranges might influence the presence or absence of hybrid intermediates. This might imply that over time and distance, with further genetic separation between parents, a hybrid entity might cease to exist quite naturally. Notwithstanding such considerations, the presence of these hybrid individuals is indicative of the close genetic similarities between like parent taxa in Australasia and China.

It is further significant that $B$. sexangula is characteristically restricted to larger, freshwater-dominated estuaries. This is most notable in northern Australia (Duke 2006). By contrast, $B$. gymnorhiza occurs in a much broader range of locations and conditions, from coastal embayments to upper estuarine reaches of tide-dominated systems. In this way, such genetically and morphologically similar species have notable niche separation, favouring quite different ecological conditions that would be expected to limit gene mixing among populations.

The fourth large, single-flowered species, $B$. exaristata, is notably distinguished from other single-flowered taxa by its slightly smaller flowers (see Table 3). Based on such observations, and our numerical analyses, $B$. exaristata may represent a more distant relative (Fig. 6). The appearance and separation of Bruguiera taxa may also have evolved in concert with floral development, progressing from ancestral entities with small flowers to those with increasingly larger flowers (see Fig. 6). All Bruguiera species appear to have a notable investment in attracting and using specific pollinators, exemplified by their distinct explosive pollen release mechanisms and attractive nectaries. Such niche specialisation of floral characters has enabled Bruguiera species to take advantage of a range of faunal vectors, with small insects attracted to smaller flowered forms, leading progressively to larger, bird-adapted flowers (Tomlinson et al. 1979, Juncosa \& Tomlinson 1987). Recent selective pressures may have favoured larger flowers with the co-appearance of progressively larger pollinators. In this way, pollinator availability, selection pressure and developing floral morphologies may have had a strong influence on speciation in this mangrove genus. This hypothesis needs to be investigated further using molecular studies.

Acknowledgements This study was financially supported in part by The University of Hong Kong, the US Forest Service, and the Australian Institute of Marine Science. Those who generously assisted with collections in various country locations include: Prof. Mei Sun (UHK) for Hainan Island, China; Drs. Jim Allen and Ken Krauss (US Forest Service) for Micronesia and Hawaii; Tim White for the Embley River, Queensland, Northern Australia; John Huckett for the Cato River, Northern Territory, Northern Australia; and Prof. Olle Björkman (Carnegie Institute) and Lee Lafferty (Daintree River Cruise Centre) for the Daintree River and Cairns, Eastern Australia.

\section{REFERENCES}

Abeysinghe, PD, Triest L, Greef BD, Koedam N, Hettiarachi S. 1999. Genetic differentiation between Bruguiera gymnorhiza and B. sexangula in Sri Lanka. Hydrobiologia 413: 11-16.

Abeysinghe PD, Triest L, Greef BD, Koedam N, Hettiarachi S. 2000. Genetic and geographic variation of the mangrove tree Bruguiera in Sri Lanka. Aquatic Botany 67: 131-141.

Allen JA, Duke NC. 2006. Large-leafed mangrove: Bruguiera gymnorrhiza. In: Elevitch CR (ed), Traditional trees of Pacific Islands: Their culture, environment and use: 139-152. Permanent Agriculture Resources, Holualoa, Hawaii. 
Allen JA, Krauss KW, Duke NC, Herbst DR, Björkman O, Shih C. 2000. Bruguiera species in Hawai'i: systematic considerations and ecological implications. Pacific Science 54: 331-343.

De Lamarck JBAP de Monnet, Poiret JLM. 1798. Encyclopedie Methodique, Botanique 4: 696 .

Duke NC. 2006. Australia's mangroves. The authoritative guide to Australia's mangrove plants. The University of Queensland and Norman C Duke, Brisbane.

Duke NC. 2010. Overlap of eastern and western mangroves in the Southwestern Pacific: hybridization of all three Rhizophora (Rhizophoraceae) combinations in New Caledonia. Blumea 55: 171-188.

Duke NC, Allen JA. 2006. Atlantic-East Pacific red mangroves: Rhizophora mangle, R. samoensis, R. racemosa, R. $\times$ harrisonii. In: Elevitch CR (ed), Traditional trees of Pacific Islands: Their culture, environment and use: 623-640. Permanent Agriculture Resources, Holualoa, Hawaii.

Duke NC, Jackes BR. 1987. A systematic revision of the mangrove genus Sonneratia (Sonneratiaceae) in Australasia. Blumea 32: 277-302.

Ge J, Cai B, Lin P. 2004. Preliminary study on the genetic diversity and differentiation of three Chinese Bruguiera gymnorrhiza populations. Nature and Science 2: 67-72.

Ge XJ. 2001. Genetic diversity and conservation genetics of mangrove species in South China and Hong Kong. PhD thesis. Zoology Department, The University of Hong Kong, Hong Kong.

Hou D. 1957. A conspectus of the genus Bruguiera (Rhizophoraceae). Nova Guinea, New Series 8, 1: 164-165.

Hou D. 1958. Bruguiera. In: Flora Malesiana, Ser. I, 5, 4: 457-468.

Islam MS, Lian CL, Kameyama N, Wu B, Hogetsu T. 2006. Development and characterization of ten new microsatellite markers in a mangrove tree species Bruguiera gymnorrhiza (L.) Lamk. Molecular Ecology Notes 6: $30-32$.
Juncosa AM, Tomlinson PB. 1987. Floral development in mangrove Rhizophoraceae. American Journal of Botany 74: 1263-1279.

Ko WC. 1978. Taxa nova Rhizophoracearum. Acta Phytotaxonomica Sinica 16: 109-110.

Pan W, Zhou HT, Chen P, Lin P. 2005. Genetic variation and relationship of three Bruguiera species by RAPD P. and ISSR. Xiamen University Institutional Repository Marine Sciences 29: 23-28.

Percival M, Womersley JS. 1975. Floristics and ecology of the mangrove vegetation of Papua and New Guinea. Department of Forests, Division of Botany, Lae, Papua New Guinea.

Sheue CR, Yong JWH, Yang YP. 2005. The Bruguiera (Rhizophoraceae) species in the mangroves of Singapore, especially on the new record and the rediscovery. Taiwania 50: 251-260.

Stearn WT. 1992. Botanical Latin, 4th ed. Timber Press, Portland.

Tomlinson PB. 1986. The botany of mangroves. Cambridge University Press, Cambridge.

Tomlinson PB, Bunt JS, Primack RB, Duke NC. 1978. Lumnitzera rosea (Combretaceae) - its status and floral morphology. Journal of the Arnold Arboretum 59: 342-351.

Tomlinson PB, Primack RB, Bunt JS. 1979. Preliminary observations on floral biology in mangrove Rhizophoraceae. Biotropica 11: 256-277.

Wagner WL, Herbst DR, Sohmer SH. 1990. Manual of the flowering plants of Hawaii. University of Hawaii Press, Honolulu.

Wyatt-Smith J. 1953. The Malayan species of Bruguiera. Malay Forester 16: $156-161$.

Zhou R, Gong X, Boufford D, Wu Cl, Shi S. 2008. Testing a hypothesis of unidirectional hybridization in plants: Observations on Sonneratia, Bruguiera and Ligularia. BMC Evolutionary Biology 8: 149. 